\title{
Eco-dyeing of wool with Rubia cordifolia root extract: Assessment of the effect of Acacia catechu as biomordant on color and fastness properties
}

\author{
Mohd Yusuf ${ }^{1 *}$, Faqeer Mohammad², Mohd Shabbir² and Mohd Ali Khan ${ }^{3}$
}

\begin{abstract}
In the present study, anthraquinone colorants were extracted from powdered Rubia cordifolia roots and applied on wool fiber. Acacia catechu is used as a biomordant, a replacement to metallic mordants, for wool dyeing, and the effect on color characteristics and fastness properties was assessed. Shades on wool of red tones with good to excellent color fastness properties were obtained. Pre-mordanting with A. catechu improved the overall color and fastness parameters, due to the maximum dye uptake. Auxochromic groups responsible for interaction of dye and wool were studied by Fourier transform infrared (FTIR) analysis of $R$. cordifolia extract. The surface morphology of dyed wool fiber was investigated by scanning electron microscopy (SEM) for any changes on fiber after dyeing.
\end{abstract}

Keywords: Natural dye, Biomordant, Color, Fastness, FTIR, Rubia cordifolia

\section{Background}

In the present context of eco-preservation, natural dyes have acquired tremendous commercial potential as some of the synthetic dyes are associated with the release of enormous amount of hazardous chemicals into the environment (Yusuf et al. 2013, 2015). The revival of interest in the use of natural dyes in textile coloration has been gaining incessant popularity all over the world, probably due to environmental concerns, eco-safety, and pollution control. Natural dyes are supposed to be friendlier and exhibit better biodegradability to the environment than their synthetic counterparts (Yusuf et al. 2015; Shabbir et al. 2016a, b). Reproducibility, inadequate availability, cost efficiency, inadequate degree of fixation, and poor color fastness properties are common discernable drawbacks of natural dyes (Cristea and Vilarem 2006; Hill 1997; Khan et al., 2012). In addition, dyes and pigments of natural origin also possess biological and biomedical activities, so they may serve as a

\footnotetext{
* Correspondence: yusuf1020@gmail.com

${ }^{1}$ Department of Chemistry, YMD College, Maharshi Dayanand University, Haryana 122107, India

Full list of author information is available at the end of the article
}

green alternative towards synthetic dyes (Yusuf et al. 2012; Velmurugan et al. 2009).

Low reactivity of natural dyes to wool has been a concern to researchers in the past, and a lot of research has been done to understand the dyeing mechanism of natural dyes on various textile substrates including wool such as adsorption and kinetic studies. Adsorption and kinetic studies suggest the reactivity behavior of wool towards natural dyes via valence forces, $\mathrm{H}$-bonding, etc., as discussed earlier also (Rather et al. 2016; Shabbir et al. 2016a, b). Although metallic mordants are used to enhance the affinity of natural dyes to textile fibers, they generate wastewater containing residual toxic metal ions which leave negative impacts on the environment and cause severe health-related problems and allergic responses (Burkinshaw and Kumar 2009; Zheng et al. 2011). In this regard, researchers searched for a greener substitute from flora and fauna. Consequently, green alternatives have been employed which have high tannin and/or metalhyperaccumulating contents (Prabhu and Teli 2014; Cunningham et al. 2011; Vankar et al. 2008; Shahid et al., 2012; Vankar and Shanker 2009). Mansour and Heffernan (2011) used Acacia catechu (cutch) as a green substitute to metal salt with impressive results also. 
A. catechu is found in most of the Indian sub-Himalayan zone. The powdered heartwood of $A$. catechu contains tannin phyto-constituents and is used for textile coloration from ancient times to impart brown tint shades on textile materials (Bhattacharya and Shah 2000; Bhattacharyya and Lohia 2002; Vankar et al. 2008; Perkin \& Everest 1918). Pharmacological studies have demonstrated that $A$. catech $u$ used in traditional medicines shows anti-inflammatory and anticancer activities (Anonymous 2006; Khan et al. 2011).

Madder (Rubia cordifolia) is a perennial and herbaceous climber plant having very long, cylindrical, and flexuous root with thin red barks. Its stems often have a long, rough, grooved, woody base. Its old roots are richer in color than the young ones. The roots contain dye present in the free or bound glucosides which are anthraquinone derivatives, mainly purpurin (CI-75410) and munjistin (CI-75370). The roots (Fig. 1) also contain a small amount of xanthopurpurin (CI-75340), pseudopurpurin (CI-75420), nordamncanthal, and rubiadin (Fig. 2.) (Color Index 1971; Mayer and Cook 1943; Anonymous 1972). Madder has been a promising plant for dyeing from the ancient times and worked upon to produce red dyed textiles of varying characteristics with the help of advance techniques and mordants (Gupta et al. 2001; Montazer and Parvinzadeh 2004; Parvinzadeh 2007). Since the modern people are more aware about eco-friendliness along with their comfort, demand for the greener textiles was raised and the evolution of biomordants gained popularity.

This study discusses the dyeing process of wool with $R$. cordifolia root extract as a natural dye, mordanting the ability of $A$. catechu and their effect on color in terms of CIEL"a*b*, color strength and fastness properties with respect to light exposure, washing, and rubbing. The structural morphology of wool fibers was evaluated by using scanning electron microscopy.

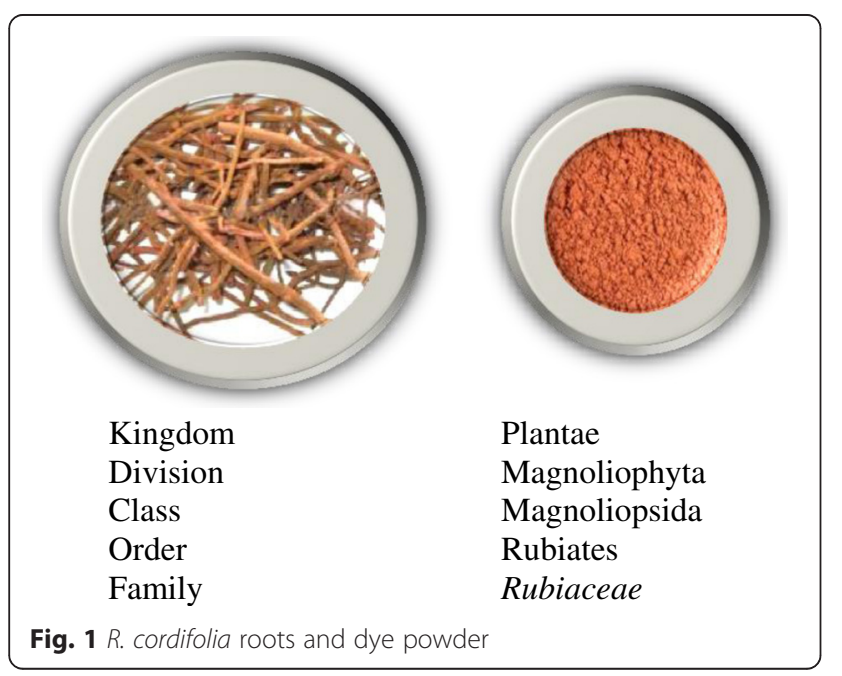

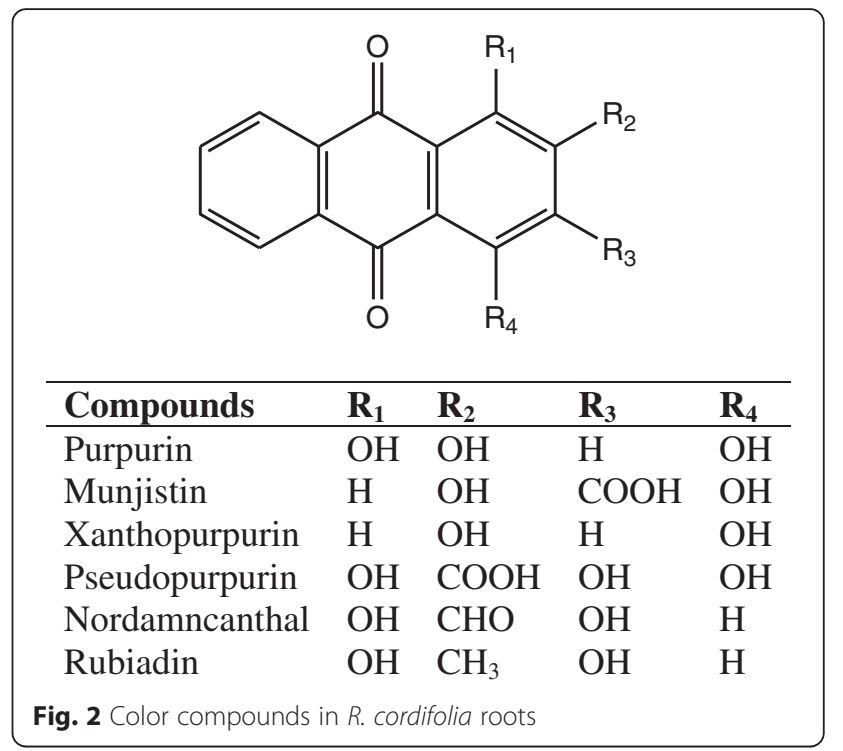

\section{Materials and Methods Materials}

Wool yarn (100\% semi-worsted 60 counts) was purchased from MAMB Woollens Ltd. Bhadohi, UP, India. A. catechu extract in powder form was purchased from Sir Biotech India Ltd. Kanpur, UP, India. Powdered madder roots were obtained from SAM Vegetables, Moradabad-244001 (UP), India. All other chemicals used were of laboratory grade.

\section{Instrumentation}

FTIR (Fourier transform infrared) spectra of $R$. cordifolia root powder were recorded on a PerkinElmer Spectrum RXI FTIR system in order to investigate the auxochromic groups responsible for wool-dye interactions (with the resolution of $4 \mathrm{~cm}^{-1}$ ). Bands in the FTIR spectra were analyzed in accordance with the literature data. A PerkinElmer Lambda-40 double-beam UV-visible spectrophotometer was employed for recording absorbance values of dye solutions to assess the dyeing absorptivity. A $\mathrm{pH} / \mathrm{mV}$ meter (BD 1011) from Decibel digital technologies was used for measuring $\mathrm{pH}$ of dye solutions. Scanning electron microscopy (SEM) technique was used to investigate the surface morphology of the wool samples before and after the application of the biomordant and dye. The samples were glued to aluminum stubs with colloidal silver paint for conductivity and sputter coated with gold for $3 \mathrm{~min}$ in an argon atmosphere. The samples were observed and digitally imaged on a LEO 435VP Scanning Electron Microscope at 10$\mathrm{kV}$ accelerating voltage.

\section{Mordanting}

Three methods of mordanting were carried out named pre-, meta-, and post-mordanting. 


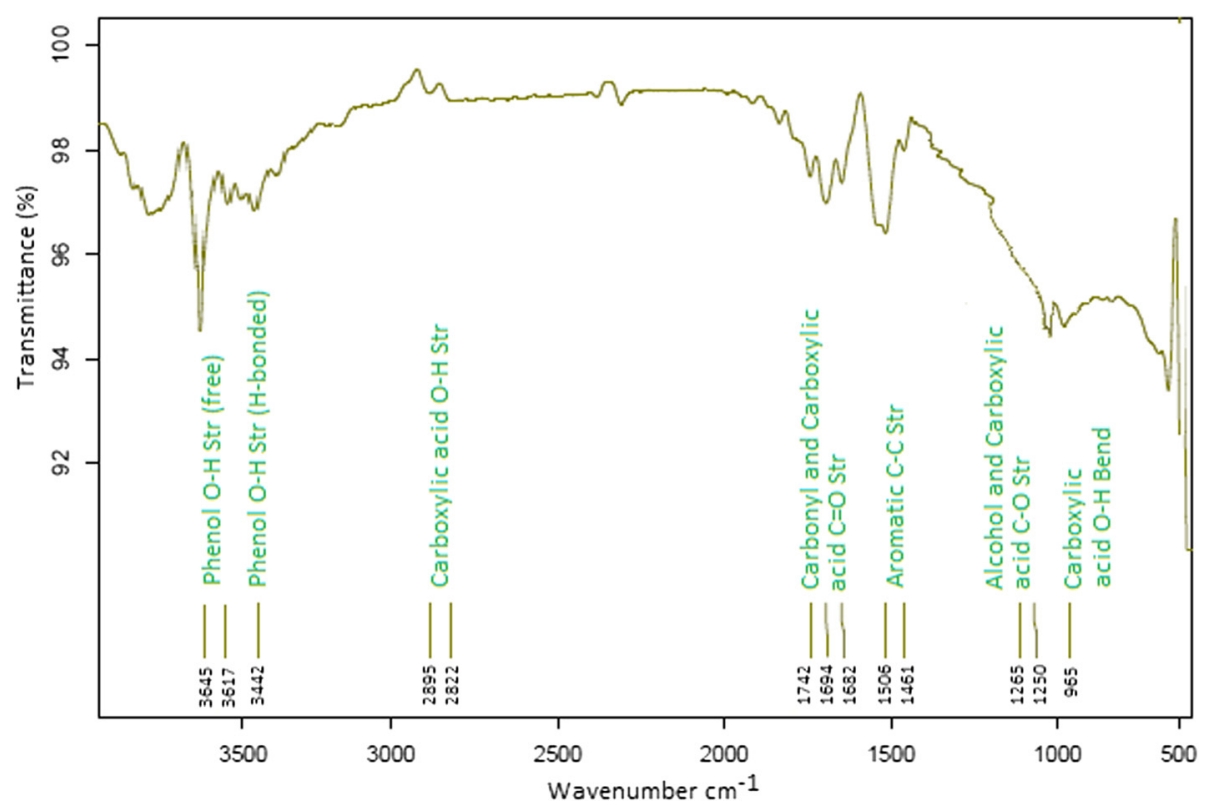

Fig. 3 FTIR spectra of $R$. cordifolia dye

\section{Pre-mordanting}

Prior to mordanting, the wool yarns were immersed in an aqueous solution containing non-ionic detergent (5 $\mathrm{mL} / \mathrm{L}$ ) for $30 \mathrm{~min}$ for removing unwanted dust from the surface of the wool. Powdered A. catechu, 5.0-0.5 \% o.w.f. (on weight of fiber), was added to water in separate baths, and the temperature of the mordant solutions was raised to $30{ }^{\circ} \mathrm{C}$ to make biomordant completely soluble. Then, water-soaked wool yarns were added to the baths. The temperature of the mordanting baths was brought to $90{ }^{\circ} \mathrm{C}$ for $1 \mathrm{~h}$ with constant stirring. Inherent $\mathrm{pH}(6.7-7.1)$ of the mordanting bath was used for mordanting. After the mordant baths were cooled, mordanted wool samples

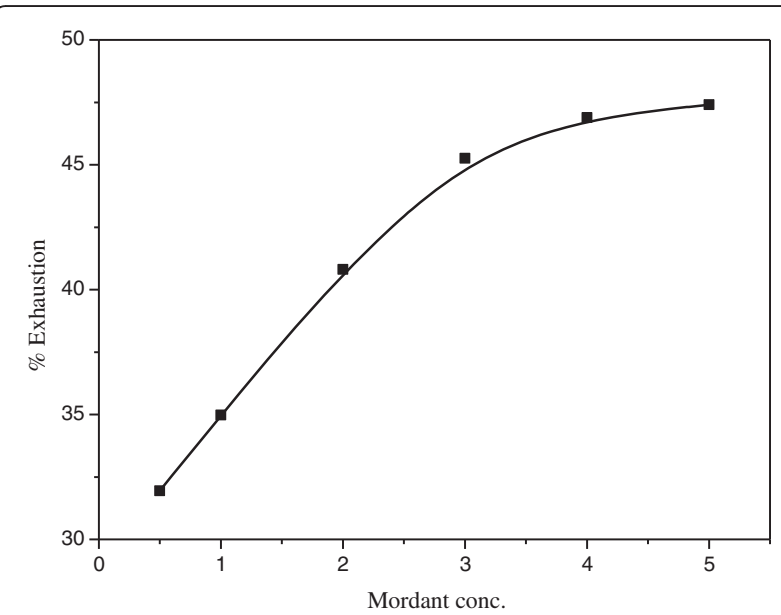

Fig. 4 Optimization of mordant concentration (\% dye exhaustion vs concentration of mordant) were removed from the mordanting baths and rinsed with tap water.

\section{Meta-mordanting}

For meta-mordanting, A. catechu powder was dissolved in water and the solution was mixed with $R$. cordifolia extract in dye bath for simultaneous mordanting and dyeing. The temperature was raised to $90{ }^{\circ} \mathrm{C}$ and kept for dyeing for $1 \mathrm{~h}$ with constant stirring.

\section{Post-mordanting}

$R$. cordifolia extract-dyed wool yarn samples were rinsed with tap water and immersed to the mordant solutions at $30{ }^{\circ} \mathrm{C}$. The temperature of the solution was raised to

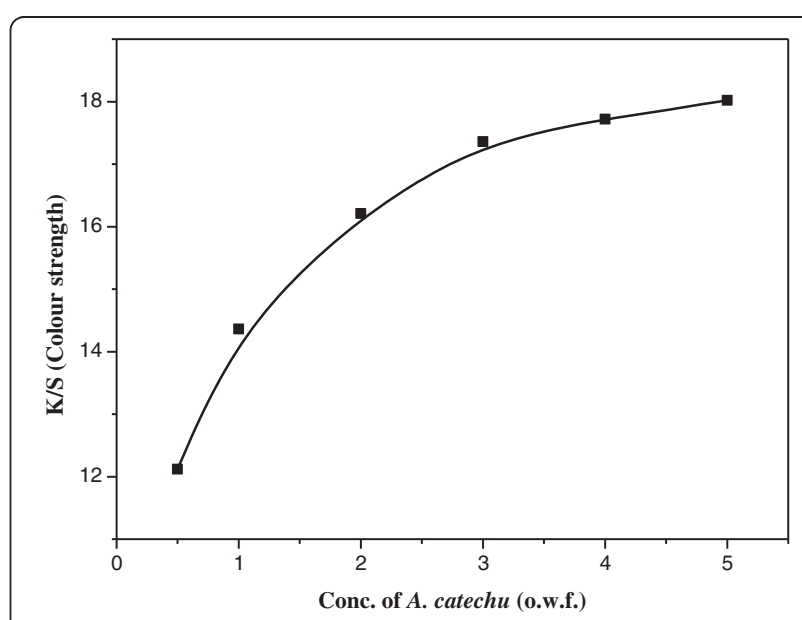

Fig. 5 Optimization of mordant concentration (color strength (K/S) vs concentration of mordant) 
Table 1 Color characteristics and color fastness properties of wool pre-mordanted with A. catechu and dyed with $R$. cordifolia

\begin{tabular}{|c|c|c|c|c|c|c|c|c|c|c|c|c|}
\hline \multirow{2}{*}{$\begin{array}{l}\text { Mordant } \\
(\%)\end{array}$} & \multirow[t]{2}{*}{$L^{*}$} & \multirow[t]{2}{*}{$a^{*}$} & \multirow[t]{2}{*}{$b^{*}$} & \multirow[t]{2}{*}{$c^{*}$} & \multirow[t]{2}{*}{$h^{\circ}$} & \multirow[t]{2}{*}{ KS } & \multirow{2}{*}{$\begin{array}{l}\text { Light } \\
\text { fastness }\end{array}$} & \multicolumn{3}{|c|}{ Wash fastness } & \multicolumn{2}{|c|}{ Rub fastness } \\
\hline & & & & & & & & c.C. & C.S. & C.W. & Dry & Wet \\
\hline $\mathrm{Nil}$ & 48.1 & 40.0 & 36.2 & 53.9 & 42.1 & 11.02 & $4 / 5$ & $3 / 4$ & $4 / 5$ & $4 / 5$ & $4 / 5$ & $3 / 4$ \\
\hline 0.5 & 46.8 & 39.2 & 30.2 & 49.5 & 37.5 & 12.12 & $4 / 5$ & 4 & $4 / 5$ & $4 / 5$ & $4 / 5$ & $3 / 4$ \\
\hline 1.0 & 42.1 & 38.8 & 25.2 & 39.1 & 32.9 & 14.36 & 5 & $4 / 5$ & $4 / 5$ & $4 / 5$ & $4 / 5$ & 4 \\
\hline 2.0 & 38.0 & 36.0 & 21.9 & 42.2 & 31.3 & 16.21 & 5 & $4 / 5$ & 5 & 5 & 5 & 4 \\
\hline 3.0 & 34.0 & 32.2 & 17.1 & 36.4 & 27.9 & 17.36 & 5 & 5 & 5 & 5 & 5 & $4 / 5$ \\
\hline 4.0 & 33.5 & 30.2 & 15.6 & 34.0 & 27.2 & 17.72 & 5 & 5 & 5 & 5 & 5 & $4 / 5$ \\
\hline 5.0 & 32.3 & 30.0 & 14.0 & 33.2 & 25.0 & 18.02 & 5 & 5 & 5 & 5 & 5 & $4 / 5$ \\
\hline
\end{tabular}

c.c. color change, c.s. color staining on cotton, c.w. color staining on wool

$90{ }^{\circ} \mathrm{C}$ with constant stirring and kept for $1 \mathrm{~h}$. Postmordanted dyed wool yarn samples were washed with non-ionic detergent and dried in shade at room temperature.

\section{Optimization of concentration of $A$. catechu}

The mordant used in this study was optimized, for pre-mordanting, for its better performance on wool in terms of achieving higher color strength and better fastness properties, and the optimized concentration was then used further for meta- and post-mordanting. Concentration of $A$. catechu mordant was optimized on the basis of absorbance values at maximum wavelength (Prabhavathi et al. 2014), recorded before and after dyeing with a UV-vis spectrophotometer, and percentage dye exhaustion was calculated by using the following equation:

$$
\% \text { Dye exhaustion }=\left[\left(A_{0}-A_{1}\right) / A_{0}\right] \times 100
$$

where $A_{0}$ and $A_{1}$ are the absorbance of the dye bath solution before and after dyeing, respectively.

Analysis of the influence of different mordanting methods, namely pre-, meta-, and post-, on the color shades of wool yarns dyed with $R$. cordifolia dye was executed through comparison with the unmordanted ones.

\section{Extraction of colorants}

Before dyeing, the colorants were extracted from the powdered madder roots. Fifty percent o.w.f. of powdered madder roots were taken in an acidic $(\mathrm{HCl})$ aqueous solution $(\mathrm{pH} 3)$ using material-to-liquor $(\mathrm{M}: \mathrm{L})$ ratio 1:20, kept overnight, boiled for $1 \mathrm{~h}$ with occasional stirring the next day, and then cooled and filtered through a clean cotton cloth. The dye bath of the extracted reddish yellow madder dye was adjusted to $\mathrm{pH} 4$ ready for dyeing of mordanted and un-mordanted wool yarn samples as previously reported in our paper (Yusuf et al. 2015).

\section{Dyeing}

The wool yarns were dyed at $\mathrm{pH} 4$ in a bath containing extracted madder dye solution at the liquor ratio of 1:40. The dyeing was started at $30{ }^{\circ} \mathrm{C}$, the temperature was gradually raised till $90{ }^{\circ} \mathrm{C}$, and dyeing was continued for $1 \mathrm{~h}$ at this temperature with stirring at regular intervals. The dyed wool yarn samples were washed with $5 \mathrm{~mL} / \mathrm{L}$ non-ionic detergent and thereafter rinsed with tap water and dried in shade at room temperature.

\section{Color measurement}

The colorimetric properties of the dyed wool yarn samples were obtained with Gretag Macbeth Color-Eye 7000 A Spectrophotometer integrated with a computer in terms of CIEL*a*b* color coordinates $\left(\mathrm{L}^{*}, \mathrm{a}^{*}, \mathrm{~b}^{*}, \mathrm{C}^{*}, \mathrm{~h}^{\circ}\right)$ and color strength values $(K / S)$. The color strength value $(K / S)$ in the visible region of the spectrum (400-
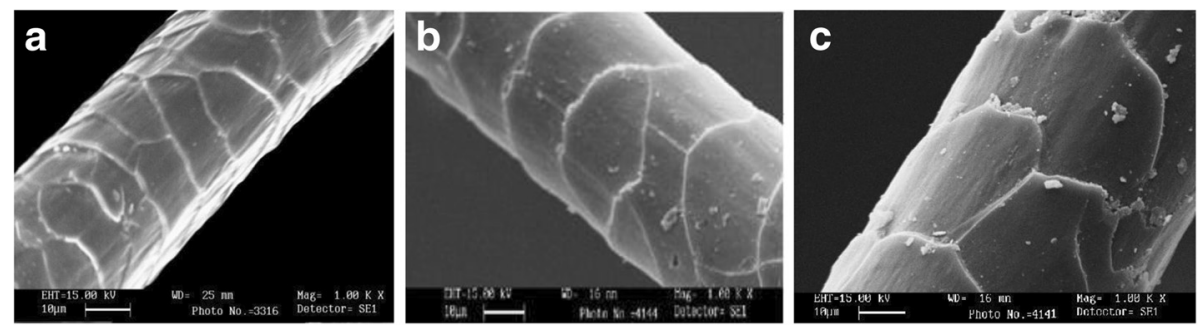

Fig. 6 SEM images showing the surface morphology of a raw wool, b A. catechu-mordanted wool, and $\mathbf{c} A$. catechu-mordanted and $R$. cordifolia-dyed wool 
Table 2 Color characteristics and color fastness properties of wool dyed with R. cordifolia and (pre-, meta-, and post-) mordanted with $3 \%$ o.w.f. A. catechu

\begin{tabular}{|c|c|c|c|c|c|c|c|c|c|c|c|c|}
\hline \multirow[t]{2}{*}{ Mordant } & \multirow[t]{2}{*}{$L^{*}$} & \multirow[t]{2}{*}{$a^{*}$} & \multirow[t]{2}{*}{$b^{*}$} & \multirow[t]{2}{*}{$c^{*}$} & \multirow[t]{2}{*}{$h^{\circ}$} & \multirow[t]{2}{*}{ K/S } & \multirow{2}{*}{$\begin{array}{l}\text { Light } \\
\text { fastness }\end{array}$} & \multicolumn{3}{|c|}{ Wash fastness } & \multicolumn{2}{|c|}{ Rub fastness } \\
\hline & & & & & & & & c.c. & C.S. & C.W. & Dry & Wet \\
\hline$\overline{\mathrm{Nil}}$ & 48.1 & 40.0 & 36.2 & 53.9 & 42.1 & 11.02 & $4 / 5$ & $3 / 4$ & $4 / 5$ & $4 / 5$ & $4 / 5$ & $3 / 4$ \\
\hline Pre-mordanted & 34.0 & 32.2 & 17.1 & 36.4 & 27.9 & 17.36 & 5 & 5 & 5 & 5 & 5 & $4 / 5$ \\
\hline Meta-mordanted & 35.2 & 31.6 & 16.1 & 35.5 & 26.9 & 14.33 & 5 & $4 / 5$ & 5 & 5 & 5 & 4 \\
\hline Post-mordanted & 34.8 & 31.9 & 16.8 & 36.0 & 27.7 & 16.81 & 5 & $4 / 5$ & 5 & 5 & 5 & 4 \\
\hline
\end{tabular}

c.c. color change, c.s. color staining on cotton, c.w. color staining on wool

$700 \mathrm{~nm}$ ) was calculated based on the Kubelka-Munk equation:

$$
\text { Color strength }(K / S)=\frac{(1-R)^{2}}{2 R}
$$

where $K$ is the absorption coefficient, $R$ is the reflectance of the dyed sample, and $S$ is the scattering coefficient.

Chroma $\left(c^{*}\right)$ and hue angles $\left(h^{\circ}\right)$ were calculated using the following equations:

$$
\begin{aligned}
& \text { Chroma }\left(\mathrm{C}^{*}\right)=\sqrt{a^{2}+b^{2}} \\
& \text { Hue angle }\left(\mathrm{h}^{\circ \circ}\right)=\tan ^{-1}\left(\frac{b}{a}\right)
\end{aligned}
$$

\section{Color fastness tests Light fastness}

The light fastness of the dyed wool yarn samples was conducted on Digi light NxTM, having water-cooled Mercury Blended Tungsten lamp as per test method AATCC 16e-2004 similar to ISO 105-B02:1994 (Amd.2:2000), which has the nearest approach to that of the sunlight. Light fastness ratings have been done on 1-8 scale as per ISO 105-B02:1994 (Amd.2:2000).

\section{Wash fastness}

The wash fastness of the dyed wool yarn samples was tested in Digi wash SSTM (Launder-o-meter) as per the ISO 105-C06:1994 (2010) specifications. The changes in color of the dyed specimens were assessed, both in terms of alteration of shades and the degree of staining on white adjacent fabrics (cotton and wool) against the standard five-point gray scale. A grade of 5 is excellent, and a grade of 1 is very poor. Color fastness rating of less than grade 3 indicates considerable alteration in color after washing.

\section{Rub fastness}

Dry and wet rub fastness of the dyed wool yarn samples was tested using a Digi crockTM (Crockmeter) as per Indian standard IS 766:1988 similar to ISO 105X12:2001 by mounting the fabric on a panel and giving ten strokes for both dry and wet rub fastness tests.

\section{Results and discussion}

FTIR spectra of $R$. cordifolia dye

FTIR analysis was used to identify the possible auxochromic functional groups responsible for the dyeability of $R$. cordifolia dye. Figure 3 represents the FTIR spectra of $R$. cordifolia dye which showed characteristic bands at 3645 and $3617 \mathrm{~cm}^{-1}$ corresponding to free phenolic

Table 3 Shade card for R. cordifolia (50.0 \% o.w.f.) dye with $3.0 \%$ Acacia catechu biomordant

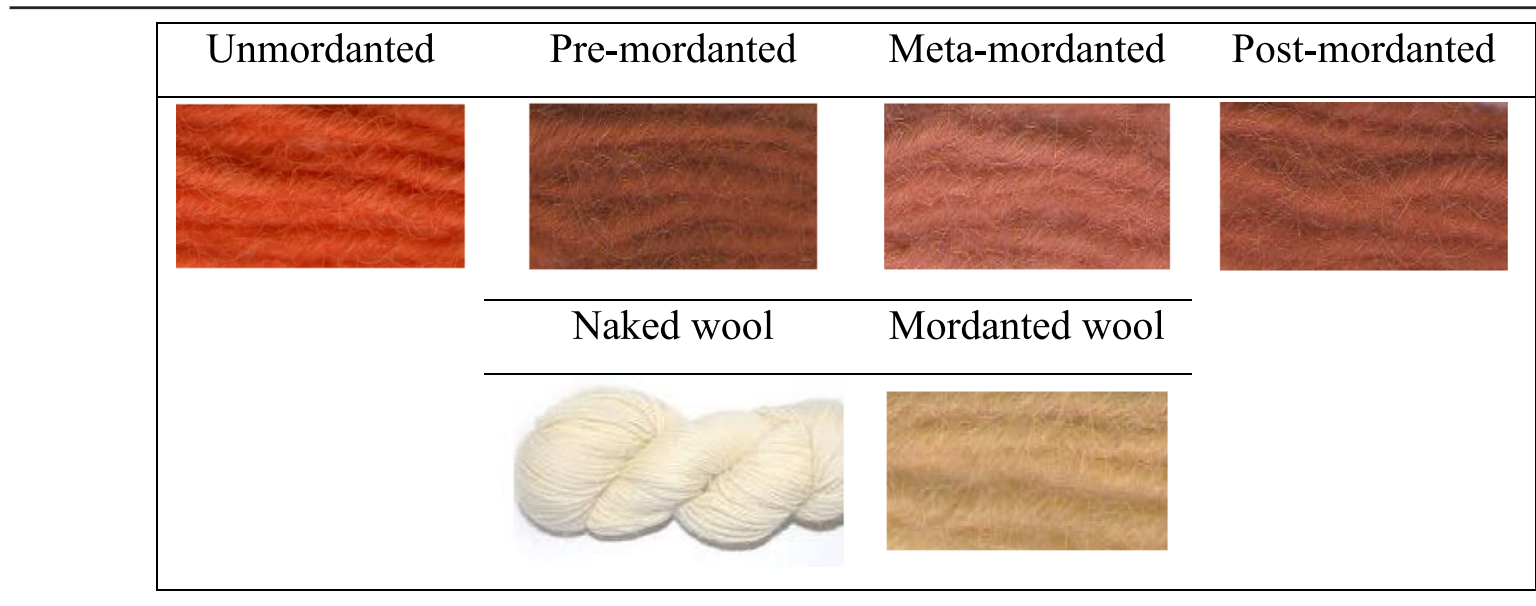




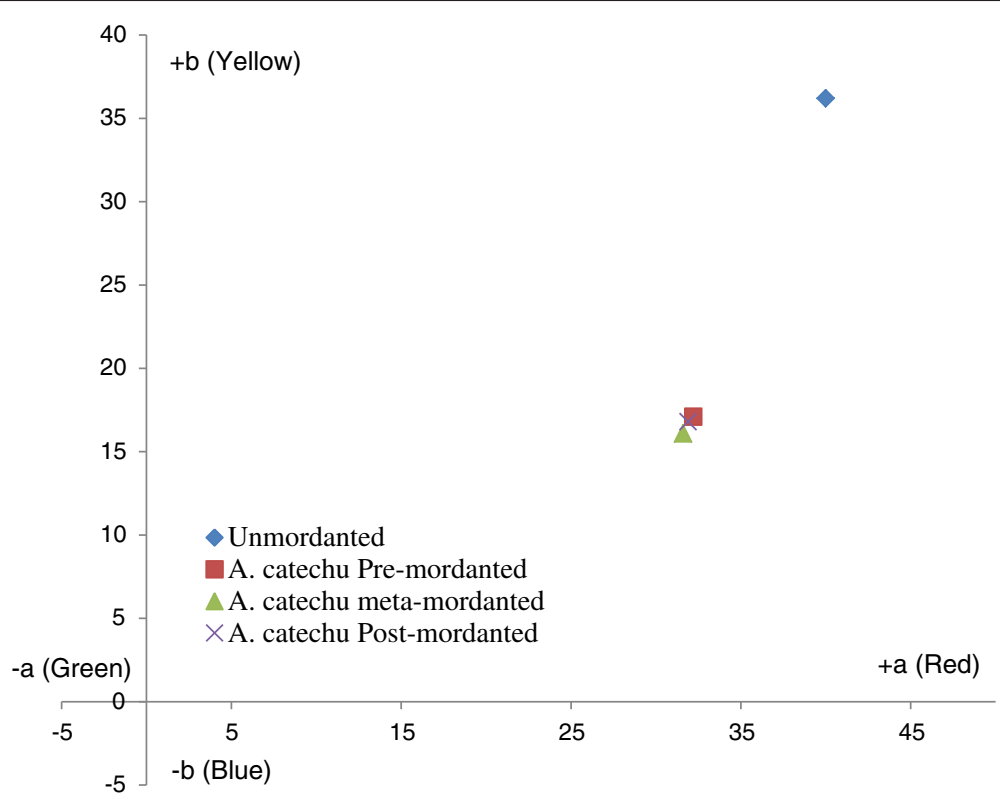

Fig. $7 a^{*}-b^{*}$ plot of wool dyed with R. cordifolia dye

$\mathrm{O}-\mathrm{H}$ stretching; $3442 \mathrm{~cm}^{-1}$ for $\mathrm{H}$-bonded phenolic $\mathrm{O}-\mathrm{H}$ stretching; 2895 and $2822 \mathrm{~cm}^{-1}$ for carboxylic acid O-H stretching; 1742, 1694, and $1682 \mathrm{~cm}^{-1}$ for carbonyl and carboxylic acid $\mathrm{C}=\mathrm{O}$ stretching; 1506 and $1461 \mathrm{~cm}^{-1}$ for aromatic $\mathrm{C}-\mathrm{C}$ stretching (in ring); 1265 and $1250 \mathrm{~cm}^{-1}$ for alcohol and carboxylic acid $\mathrm{C}-\mathrm{O}$ stretching; and $965 \mathrm{~cm}^{-1}$ for carboxylic acid $\mathrm{O}-\mathrm{H}$ bending. These results demonstrate the existence of anthraquinone compounds in $R$. cordifolia dye (Nakahara and Fukuda 1979; Richardson et al. 1988).

\section{Optimization of biomordant concentration}

Figures 4 and 5 depict the optimization of $A$. catechu as a biomordant on the basis of \% dye exhaustion and color

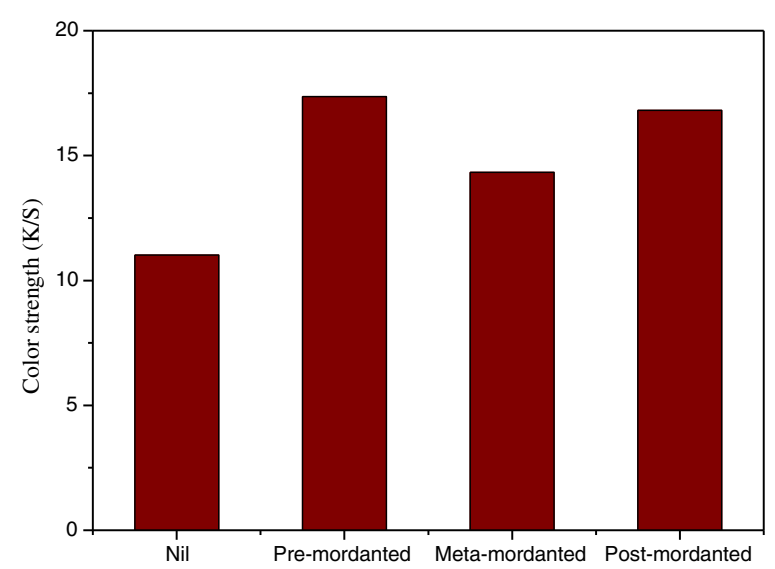

Fig. 8 Effect of mordanting methods on wool mordanted with $3 \%$ o.w.f. A. catechu and dyed with $R$. cordifolia on color strength strength $(K / S)$, respectively. It can be observed that there is a gradual increase in \% dye exhaustion and color strength $(K / S)$ of pre-mordanted wool yarn samples when the concentration of $A$. catechu reached to $3 \%$ o.w.f., and thereafter, a little increment occurred. Thus, $3 \%$ biomordant is believed to be the optimized mordant concentration for subsequent dyeing experiments with $R$. cordifolia natural dye.

\section{Scanning electron microscopy analysis}

The morphological features of wool fibers are depicted in Fig. 6, and it can be seen clearly that a wool fiber consists of scaled and fibrillar structures (Fig. 6a). Figure 6b, c represents the surface of mordanted and dyed wool fibers which were seen without any physical changes such as cracks on surface, responsible for alteration of wool fiber properties.

\section{Color characteristics}

Colorimetric characteristics (CIEL*a*b* and $K / S$ values) of wool yarn mordanted with $A$. catechu and dyed with $R$. cordifolia were analyzed and presented in Tables 1 and 2. Orange red and dark brown red shades are obtained by $R$. cordifolia dye of different hue and tones, with or without mordant (A. catechu). A drastic decrease in lightness values is observed in the case of biomordanted samples in comparison to the control dyed samples (Table 3). All the dyed wool samples appeared in red-yellow zone of CIEL*a*b* color space (Fig. 7). 
<smiles>CCCCN(C)C(C)C(=O)NCC</smiles>

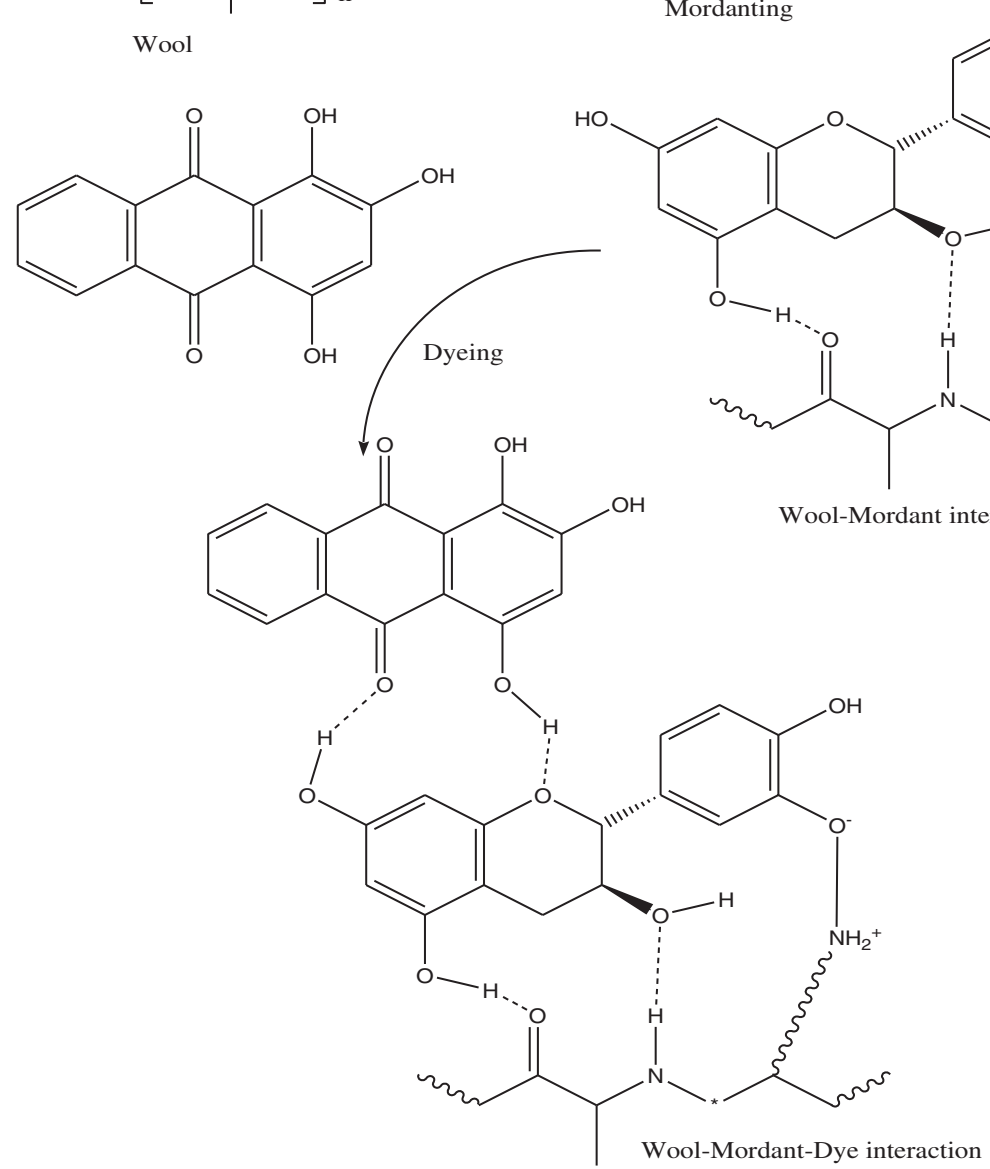

Fig. 9 Schematic representation of probable dyeing mechanism

\section{Effect of mordanting methods}

In comparison to the control dyed wool yarn, A. catechu-mordanted, dyed samples were found to be darker. It was found that the darkening effect reached to maximum in the case of pre-mordanting method in comparison to the post- and meta-mordanting methods. From Fig. 8, it can be seen that the trend of color strength is found to be decreasing from $A$. catechu premordanted to A. catechu post-mordanted and A. catechu meta-mordanted. Meta-mordanted dyed wool samples have the lowest color strength owing to the interaction of dye and biomordant molecules in dye bath solution and low amount of dye interacts to fiber. $a^{*}-b^{*}$ plot shows shifting of the coordinates towards the red-green axis in all cases of mordanting methods.

\section{Color fastness properties}

Tables 1 and 2 show the fastness properties of control and mordanted dyed with $R$. cordifolia wool samples. It can be seen from the data that mordanting markedly enhances the overall fastness properties, and the best results are observed in the pre-mordanting ones to a significant extent that are commercially acceptable.

Wool fiber is a polypeptide and has many active sites in which a dye can bind to the fiber. It may form covalent or ionic bonding to the $-\mathrm{NH}_{2}$ and $-\mathrm{COOH}$ groups on the ends of the polymer or form similar interactions with the amino acid side chains resulting in significant colorimetric and fastness properties. The chemistry of bonding of dyes to fiber is very complex. In fact, bonding occurs in different ways such as direct bonding 
(covalent), H-bonding, and hydrophobic interactions (van der Waals forces). Mordants help in binding of dyes to fiber by forming a chemical bridge between the dye and the fiber, thus improving the substantivity of a dye along with increase in fabric's color fastness properties and color depth as well (Fig. 9). Recently, Vankar et al. (2008) observed that Eurya acuminata when used as a mordant in conjunction with $R$. cordifolia dye was found to enhance the dyeability of silk fabric by chelation due to the high $\mathrm{Al}$ content present in its leaves. In another study, Cu-hyperaccumulating plant Pyrus pashia has been reported to provide better dye adherence due to stronger and useful chelation to the flavone/flavonol dyes extracted from Delonix regia (Vankar and Shanker 2009). Mansour and Heffernan (2011) have found that being a tannin-rich species, $A$. catechu is an instrumental tool in the enhancement of dyeability of dye used for textile fabric. In addition, the use of plants as a natural green alternative to metallic mordants is a very promising concept which may help to reduce the enormous environmental risks associated with metal salt mordants.

\section{Conclusions}

This study evaluated the effect of color and fastness properties of wool fibers dyed with $R$. cordifolia as a natural dye and $A$. catechu as anchoring agent. The colorimetric (CIE $\left.\mathrm{L}^{*} \mathrm{a}^{*} \mathrm{~b} *\right)$ and fastness properties were considerably improved using $A$. catechu as a biomordant and $R$. cordifolia as a natural dye which may be profitably acceptable in industrial and commercial spheres. The pre-mordanting method found more overdriven effects than the meta-mordanting and post-mordanting methods overall. In order to obtain more eco-friendly and biocompatible dyeing, the current study demonstrated a cleaner approach by using $A$. catechu as a biomordant to minimize the pollution with substitution of metallic salts to fulfill the demand of the world in contemporary scenario.

\section{Acknowledgements}

The authors are grateful to UGC, New Delhi, for BSR Fellowship (MS) and Dr. M. I. Khan, Principal, YMD College, for providing the working facilities to this research.

\section{Authors' contributions}

MY and FM designed the experiment. MY conducted all of the experimental procedures and interpreted the tentative data. MS drafted the manuscript, and MAK provided technical help. All authors read and approved the final manuscript submission.

\section{Competing interests}

The authors declare that they have no competing interests.

\section{Author details}

'Department of Chemistry, YMD College, Maharshi Dayanand University, Haryana 122107, India. ${ }^{2}$ Department of Chemistry, Jamia Millia Islamia (A Central University), New Delhi 110025, India. ${ }^{3}$ Department of Post Harvest Engineering and Technology, Aligarh Muslim University, Aligarh 202002, India.
Received: 16 February 2016 Accepted: 1 July 2016

Published online: 11 July 2016

\section{References}

Anonymous. (1972). The wealth of India raw materials, National Institute of Science Communication and Information Resources. New Delhi: CSIR. Vol. 9, Rh-So, 82-83. Anonymous. (2006). The wealth of India raw materials, National Institute of Science Communication and Information Resources. New Delhi: CSIR. Vol. 1, A-F, 7-8.

Bhattacharya, S. D., \& Shah, A. K. (2000). Metal ion effect on dyeing of wool fabric with catechu. Journal of Society of Dyers and Colorists, 116, 10-12.

Bhattacharyya, N., \& Lohia, N. (2002). Dyeing of cotton and polyester fiber with pomegranate rind, catechu, nova red and turmeric. Asian Textile Journal, 11, 70-74.

Burkinshaw, S. M., \& Kumar, N. (2009). The mordant dyeing of wool using tannic and $\mathrm{FeSO}_{4}$, part 1: initial findings. Dyes and Pigments, 80, 53-60.

Color Index, 1971. $3^{\text {rd }}$ edn., Society of dyers and colorists (SDC), Bradford, UK, 4, 4630-4631

Cristea, D., \& Vilarem, G. (2006). Improving light fastness of natural dyes on cotton yarn. Dyes and Pigments, 70, 238-248.

Cunningham, A. B., Maduarta, I. M., Howe, J., Ingram, W., \& Jansen, S. (2011) Hanging by a thread: natural metallic mordant processes in traditional Indonesian textiles. Economical Botany, 65, 241-259.

Gupta, D., Kumari, S., \& Gulrajani, M. (2001). Dyeing studies with hydroxyanthraquinones extracted from Indian madder. Part 2: dyeing of nylon and polyester with nordamncanthalt. Coloration Technology, 117(6), 333-336.

Hill, D. J. (1997). Is there a future for natural dyes? Reviews in progress and coloration, 27, 18-25.

Khan, M. I., Ahmad, A., Khan, S. A., Yusuf, M., Shahid, M., Manzoor, N., et al. (2011). Assessment of antimicrobial activity of catechu and its dyed substrate. Journal of Cleaner Production, 19(12), 1385-1394.

Khan, S. A., Ahmad, A., Khan, M. I., Yusuf, M., Shahid, M., Manzoor, N., et al. (2012). Antimicrobial activity of wool yarn dyed with Rheum emodi L. (Indian Rhubarb). Dyes and Pigments, 95(2), 206-214.

Mansour, H. F., \& Heffernan, S. (2011). Environmental aspects on dyeing silk fabric with Sticta coronate lichen using ultrasonic energy and mild mordants. Clean Technologies and Environmental Policy, 13, 207-213.

Mayer, F., \& Cook, A. H. (1943). The chemistry of natural coloring matters (pp. 120-124). USA: Reinhold Publishing Corporation.

Montazer, M., \& Parvinzadeh, M. (2004). Effect of ammonia on madder-dyed natural protein fiber. Journal of applied polymer science, 93(6), 2704-2710.

Nakahara, H., \& Fukuda, K. (1979). Studies on molecular orientation in multilayers of long-chain anthraquinone derivatives by polarized infrared spectra. Journal of Colloid and Interface Science, 69(1), 24-33.

Parvinzadeh, M. (2007). Effect of proteolytic enzyme on dyeing of wool with madder. Enzyme and Microbial Technology, 40(7), 1719-1722.

Perkin, A. G., \& Everest, A. E. (1918). Natural organic coloring matters (pp. 41-42). London: Longmans Green and Co.

Prabhavathi, R., Devi, A. S., \& Anitha, D. (2014). Improving the colour fastness of the selected natural dyes on cotton. IOSR Journal of Polymer and Textile Engineering, 1(4), 21-26.

Prabhu, K. H., \& Teli, M. D. (2014). Eco-dyeing using Tamarindus indica L. seed coat tannin as a natural mordant for textiles with antibacterial activity. Journal of Saudi Chemical Society, 18(6), 864-872.

Rather, L. J., Shahid-ul-Islam, Azam, M., Shabbir, M., Bukhari, M. N., Shahid, M., Khan, M. A., Haque, Q. M. R., \& Mohammad, F. (2016). Antimicrobial and fluorescence finishing of wool yarn with Terminalia arjuna natural dye as an ecofriendly substitute to synthetic antibacterial agents. RSC Advances, 6(45), 39080-39094.

Richardson, W. H., Schmidt, T. M., \& Nealson, K. H. (1988). Identification of an anthraquinone pigment and a hydroxystilbene antibiotic from Xenorhabdus luminescens. Applied and Environmental Microbiology, 54(6), 1602-1605.

Shabbir, M., Shahid UI, I., Bukhari, M. N., Rather, L. J., Khan, M. A., \& Mohammad, F. (2016a). Application of Terminalia chebula natural dye on wool fiberevaluation of color and fastness properties. Textiles and Clothing Sustainability, 2(1), 1-9.

Shabbir, M., Rather, L. J., Shahid-ul-Islam, Bukhari, M. N., Shahid, M., Khan, M. A., \& Mohammad, F. (2016b). An eco-friendly dyeing of wool yarn by Terminalia chebula extract with evaluations of kinetic and adsorption characteristics. Journal of advanced research, 7(3), 473-482. 
Shahid, M., Ahmad, A., Yusuf, M., Khan, M. I., Khan, S. A., Manzoor, N., et al. (2012). Dyeing, fastness and antimicrobial properties of wool yarns dyed with gallnut (Quercus infectoria Oliv.) extract. Dyes and Pigments, 95(1), 53-61.

Vankar, P. S., \& Shanker, R. (2009). Eco-friendly pretreatment of silk fabric for dyeing with Delonix regia extract. Coloration Technology, 125, 155-160.

Vankar, P. S., Shanker, R., Mahanta, D., \& Tiwari, S. C. (2008). Ecofriendly sonicator dyeing of cotton with Rubia cordifolia Linn. using biomordants. Dyes and Pigments, 76, 207-212.

Velmurugan, P., Chae, J. C., Lakshmanaperumalasamy, P., Yun, B. S., Lee, K. J., \& Oh, B. T. (2009). Assessment of the dyeing properties of pigments from five fungi and anti-bacterial activity of dyed cotton fabric and leather. Color. Technol., 125, 334-341.

Yusuf, M., Ahmad, A., Shahid, M., Khan, M. I., Khan, S. A., Manzoor, N., et al. (2012). Assessment of colorimetric, antibacterial and antifungal properties of woollen yarn dyed with the extract of the leaves of henna (Lawsonia inermis). Journal of Cleaner Production, 27, 42-50.

Yusuf, M., Shahid, M., Khan, S. A., Khan, M. I., Shahid-ul-Islam, Mohammad, F., et al. (2013). Eco-dyeing of wool using aqueous extract of the roots of Indian madder (Rubia cordifolia) as natural dye. Journal of Natural Fibers, 10, 14-28.

Yusuf, M., Shahid, M., Khan, M. I., Khan, S. A., Mohammad, F., \& Khan, M. A. (2015). Dyeing studies with henna and madder: a research on effect of tin (II) chloride mordant. Journal of Saudi Chemical Society, 19, 64-72.

Zheng, G. H., Fu, H. B., \& Liu, G. P. (2011). Application of rare earth as mordant for the dyeing of ramie fabrics with natural dyes. Korean Journal of Chemical Engineering, 28, 2148-2155.

\section{Submit your manuscript to a SpringerOpen ${ }^{\odot}$ journal and benefit from:}

- Convenient online submission

- Rigorous peer review

- Immediate publication on acceptance

- Open access: articles freely available online

- High visibility within the field

Retaining the copyright to your article

Submit your next manuscript at $\gg$ springeropen.com 